\title{
Quantitative Studies of Phagocytosis by
}

\section{Polymorphonuclear Leukocytes: Use of Emulsions}

to Measure the Initial Rate of Phagocytosis

\author{
Thomas P. Stossel, Robert J. Mason, John Hartwig, and \\ Martha Vaughan \\ From the Molecular Disease Branch, National Heart and Lung Institute, \\ National Institutes of Health, Bethesda, Maryland 20014
}

\begin{abstract}
A B S T R A C T Polymorphonuclear leukocytes suspended in Krebs-Ringer phosphate medium ingest paraffin oil containing Oil Red $\mathrm{O}$ emulsified with a variety of substances. Spectrophotometric determination of Oil Red $O$ in the cells after uningested particles have been removed by differential centrifugation provides a quantitative measure of phagocytosis. This system has been used to investigate the effects of several drugs and hormones on the initial rate of phagocytosis and to approach the question of how the surface of a particle influences its acceptability as a substrate for phagocytosis. The rate of uptake of paraffin oil emulsified with bovine albumin was constant for $6 \mathrm{~min}$ and was proportional to cell concentration when saturating concentrations of paraffin oil emulsion were used. At lower concentrations of substrate, the initial rate of phagocytosis was directly proportional to paraffin oil concentration. The increment in glucose oxidation associated with phagocytosis varied directly with the initial rate of particle uptake. The rate of ingestion of the albumin emulsion was not altered by serum $(2-20 \%$, v/v), glucose (5-20 mm), or omission of potassium from the medium. The rate of phagocytosis was decreased $65 \%$ if magnesium was omitted, and was essentially zero in the absence of divalent cations. The initial rate of uptake was inhibited by inhibitors of glycolysis, by $N$ ethylmaleimide (0.05-1 $\mathrm{mm})$, colchicine (0.001-0.1 $\mathrm{mm}$ ), theophylline ( 1 and $2 \mathrm{~mm}$ ), dibutyryl cyclic AMP (1
\end{abstract}

Dr. Stossel's and Mr. Hartwig's present address is Hematology Division, Children's Hospital Medical Center, Boston, Mass. 02115. Dr. Mason's present address is Cardiovascular Research Institute, University of California, San Francisco, Calif. 94122.

Received for publication 21 July 1971 and in revised form 1 November 1971. $\mathrm{mm}$ ), hydrocortisone (2.1 $\mathrm{mm}$ ), and ethanol (85 $\mathrm{mm}$ ). Inhibitors of oxidative phosphorylation and dexamethasone $(0.01 \mathrm{mM})$ were without effect, while insulin (2 $\mathrm{mU} / \mathrm{ml}$ ) slightly stimulated the phagocytic rate. Paraffin oil emulsified with different agents was used to approach the question of how the surface of a particle influences its acceptability as a substrate for phagocytosis. Emulsions prepared with nonionic detergents, methylated proteins, and proteins with a weak net charge at $\mathrm{pH} 7.4$ were poorly ingested. On the other hand emulsions prepared with agents of strong net positive or negative charge were rapidly taken up. The effect of divalent cations on the rate of phagocytosis varied with the nature of the emulsifier, but was not related in any simple, direct fashion to the net surface charge of the particles. However, it has not been conclusively established that charge was the only variable of the emulsion particles employed.

\section{INTRODUCTION}

Phagocytosis is an integrated series of complex events. Certain as yet unidentified characteristics of the surface of a particle cause it to be bound to the plasma membrane of a polymorphonuclear leukocyte which then internalizes it. As the phagocytic vesicle is formed and moves centripetally, lysosomal granules discharge their contents into it and disappear from the cytoplasm, a process termed degranulation. These processes are accompanied by several alterations in the metabolism of the phagocytic cell which have been termed metabolic concomitants of phagocytosis. One of these is an increase in oxidation of glucose via the hexose monosphaphate shunt (1). 
During earlier studies (2) in which phagocytic vesicles were isolated, we observed that paraffin oil, emulsified with bovine albumin, was avidly ingested by polymorphonuclear leukocytes, and that uningested particles were easily washed from the cells. When the paraffin oil was colored with Oil Red O, a highly satisfactory assay for the rate of phagocytosis was established. Paraffin oil is only minimally metabolized (3) and is therefore suitable for studies of biochemical responses to phagocytosis as well. As reported below, we have used this system to investigate the effects of several drugs and hormones on the initial rate of phagocytosis and have correlated the initial rate of phagocytosis with the increment in rate of glucose oxidation in cells incubated with varying concentrations of emulsion (substrate for phagocytosis). In addition, as an approach to the question of how the surface of a particle influences its acceptability as a substrate for phagocytosis, we have determined the rates of uptake of paraffin oil emulsified with a variety of substances.

\section{METHODS}

Suspensions containing over $95 \%$ polymorphonuclear leukocytes were collected from rat and guinea pig peritoneal exudates induced with sodium caseinate; and human peripheral blood leukocytes were collected and washed as previously described (2). Emulsions of heavy paraffin oil were prepared as previously described (2). In a $2 \times 6 \mathrm{~cm}$ plastic test tube $1 \mathrm{ml}$ of heavy paraffin oil (Fisher Scientific Company, Pittsburgh, $\mathrm{Pa}$.) containing Oil Red $\mathrm{O}$ (Allied Chemical Corp., Morristown, N. J.) was layered over $3 \mathrm{ml}$ of Krebs-Ringer phosphate medium, $\mathrm{pH} 7.4$, containing onethird the recommended amount of calcium (hereafter referred to as Krebs-Ringer phosphate medium) into which was dissolved the appropriate emulsifying agent. The final $\mathrm{pH}$ was adjusted to 7.4. The $2 \mathrm{~mm}$ tip of a Branson model LS-75 sonifier (Branson Instruments Co., Stamford, Conn.) was placed just below the lower level of the oil-liquid interface. Dispersion was achieved at a setting of $2.8 \mathrm{amp}$ for 90 sec. For most studies Oil Red O was dissolved directly in the paraffin oil (2), but greater concentrations of the dye in the oil were achieved by dissolving Oil Red $O$ in chloroform, mixing this with the paraffin oil, and then removing the chloroform under vacuum at $60^{\circ} \mathrm{C}$.

After preliminary experiments had established the time course of particle uptake, the following standard incubation system was utilized. Cells (3-5 $\mathrm{mg}$ of cell protein $/ \mathrm{ml}$ or approximately $5 \% \mathrm{v} / \mathrm{v}$ ) were incubated in Krebs-Ringer

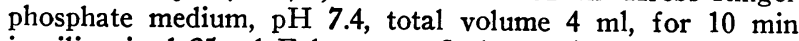
in siliconized $25 \mathrm{ml}$ Erlenmeyer flasks at $37^{\circ} \mathrm{C}$ in a shaking water bath at 100 strokes per min. During this interval, agents to be tested were present in the medium. Then $1 \mathrm{ml}$ of freshly prepared paraffin oil emulsion prewarmed to $37^{\circ} \mathrm{C}$ was added to the flask. Duplicate $1 \mathrm{ml}$ samples (zero time) of cells and medium were immediately transferred with an Eppendorf automatic pipette to siliconized 15-ml glass centrifuge tubes containing $6 \mathrm{ml}$ of ice-cold $0.15 \mathrm{M}$ $\mathrm{NaCl}$ with $1 \mathrm{~mm} N$-ethylmaleimide. The incubation was continued, and at $4 \mathrm{~min} 1 \mathrm{ml}$ samples were again taken. For most studies duplicate flasks containing the complete medium without additions were incubated as controls. The experimental flasks were incubated singly, in duplicate, or occasionally in triplicate. All sampling from individual flasks was in duplicate.

The samples were centrifuged for $10 \mathrm{~min}$ at $150 \mathrm{~g}$. The tubes were grasped at the supernatant fluid level, held upright, and shaken horizontally. This procedure dislodged the rim of uningested oil particles which had floated to the meniscus. It was then discarded along with the supernatant fluid. The cell pellet was gently dispersed by tapping the bottom of the tube. The washing procedure was repeated twice, and the tubes were drained by inversion. Oil Red $\mathrm{O}$ was extracted from the washed pellets with 1-3 ml of $p$-dioxane (J. T. Baker Chemical Co., Phillipsburg, N. J.) at room temperature. The extracts were centrifuged for $15 \mathrm{~min}$ at $1000 \mathrm{~g}$ and the optical density at $524 \mathrm{~m} \mu$ was determined. Differences between duplicate samples from the same flask were always less than $5 \%$ and usually less than $2 \%$. Rates of phagocytosis are expressed in terms of optical density at $524 \mathrm{~m} \mu$ or milligrams of paraffin oil per milligram cell protein per minute after subtraction of zero time values.

For measurement of glucose oxidation, the incubation conditions were essentially as described above with the following exceptions. The medium contained glucose-1-14 $\mathrm{C}$ (47.8 $\mathrm{mCi} / \mathrm{mmole}$ ) plus $5 \mathrm{~mm}$ glucose carrier. After the particles were added, the flasks were stoppered and ${ }^{14} \mathrm{CO}_{2}$ was collected and counted as described previously (4).

The emulsifiers were present in a concentration of 20 $\mathrm{mg} / \mathrm{ml}$ of aqueous phase during preparation of the particles. Fraction V from bovine serum, Lot D26304, and crystalline bovine albumin, Lot F71703, were purchased from Armour Pharmaceutical Co., Chicago, Ill. Crystalline bovine albumin was delipidated (5), acetylated (6), succinylated (7), or methylated (8). Gelatin was purchased from Nutritional Biochemicals Corporation, Cleveland, Ohio, and methylated (8). Polylysyl-gelatin was prepared with $N$, $N^{\prime}$-di-carbo-benzoxy-L-lysine anhydride $(9,10)$. The anhydride was synthesized from $N, N^{\prime}$-di-carbobenzoxy-L-lysine (Sigma Chemical Co., St. Louis, Mo.) (11) and recrystallized from ethyl acetate and petroleum ether. The extent of derivatization of the proteins was determined by paper electrophoresis in $0.1 \mathrm{M}$ phosphate buffer, $\mathrm{pH}$ 7.4. Calf thymus histone (type II-A, Lot 99B-1840) and lysine-rich histone were purchased from Sigma and dialyzed against $2 \mathrm{mM}$ EDTA and $0.15 \mathrm{M} \mathrm{NaCl}$. Cytochrome c was obtained from Calbiochem, Los Angeles, Calif., and horseradish peroxidase from Worthington Biochemical Corp., Freehold, N. J. Soluble starch (Merck \& Co., Inc., Rahway, N. J.) was reprecipitated twice from $80 \%$ methanol. The starch, heparin (Hynson, Wescott \& Dunning, Inc., Baltimore, Md.), dextran (2 million mol wt), DEAEdextran-sulfate (Pharmacia, Uppsala, Sweden) were dissolved in boiling water and diluted in Krebs-Ringer phosphate medium before use. Polyoxyethylene-polyoxypropylene polymers (Pluronic F108 and F68) were supplied by the Wyandotte Chemicals Corp., Wyandotte, Mich., through the courtesy of Dr. Irving Schmolka. Tween 20 was purchased from Schwarz/Mann, Orangeburg, N. Y. and used in a concentration of $0.01 \%$. Sodium $N$-lauryl sacrosinate, sodium $N$-lauryl sulfate, and acetyl dimethylbenzyl ammonium chloride were gifts of the Onyx Chemical Corporation, Jersey City, N. J. and were used in $0.01 \%$ concentrations.

Solutions of drugs in Krebs-Ringer phosphate medium were freshly prepared for each experiment. Colchicine, Lot 800585, was purchased from Calbiochem, Los Angeles, Calif.; theophylline and $N$-ethylmaleimide from Nutritional 
Biochemicals Corporation, Cleveland, Ohio, Hydrocortisone 21-succinate from Sigma Chemical Co., St. Louis, Mo.; ouabain, Lot N2026, from Mann Research Labs, Inc., New York; dexamethasone phosphate from Merck \& Co., Inc., Rahway, N. J.; and $\mathrm{N}^{6}, 2^{\prime} 0$-dibutyryl $3^{\prime}, 5^{\prime}$-cyclic adenosine monophosphate (dibutyryl cyclic AMP, Lot 06239415) from Boehringer. \& Soehne, Mannheim, W. Germany. Amorphous insulin, a gift from Eli Lilly \& Co., Indianapolis, Ind., was stored in solution with $40 \mu \mathrm{g} / \mathrm{ml}$ albumin at $-20^{\circ} \mathrm{C}$.

Rabbit antiserum to bovine albumin was purchased from Difco Laboratories, Detroit, Mich. Guinea pig blood was obtained by cardiac puncture and allowed to clot in glass containers. The serum was separated by centrifugation and stored in lots at $-70^{\circ} \mathrm{C}$.

\section{RESULTS}

Kinetics of phagocytosis of paraffin oil emulsion. The data in Figs. 1-3 were obtained with guinea pig peritoneal exudate polymorphonuclear leukocytes suspended in Krebs-Ringer phosphate medium without glucose. The substrate for phagocytosis was paraffin oil emulsified with Fraction V from bovine serum. In the presence of a saturating quantity of particles, the rate of ingestion was constant for $5 \mathrm{~min}$ after a brief delay (Fig. 1). As shown in Fig. 2, with about $3 \mathrm{mg}$ of cell protein per $\mathrm{ml}$, the initial rate of phagocytosis was essentially independent of substrate concentration above $10 \%$ (volume of emulsion added per total incubation volume). With $20 \%$ substrate, uptake during the first 4 min of incubation was directly proportional to cell concentration between 1 and $2.5 \mathrm{ml}$ cell protein per $\mathrm{ml}$ (Fig. 3). When lower concentrations of cells were used (as little as $0.3 \mathrm{mg} / \mathrm{ml}$ ) this proportionality was maintained. When the Fraction V emulsion was used, essen-

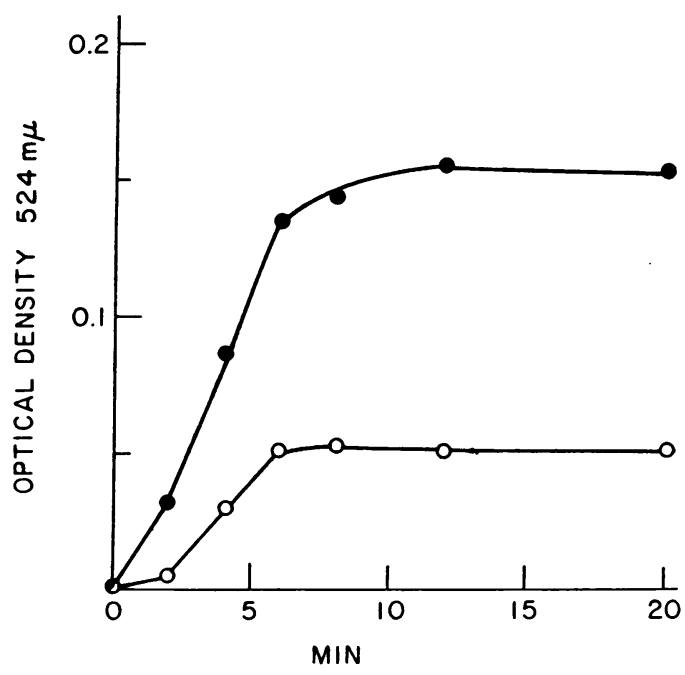

FigUre 1 Time course of uptake of paraffin oil emulsified with Fraction V. Guinea pig polymorphonuclear leukocytes, $2.9 \mathrm{mg}$ cell protein $/ \mathrm{ml}(\bullet)$ or $0.96 \mathrm{mg} / \mathrm{ml}(O)$, were incubated with $0.2 \mathrm{ml}$ Fraction $\mathrm{V}$ emulsion $/ \mathrm{ml}$ final volume. Each point is the mean of duplicate values.

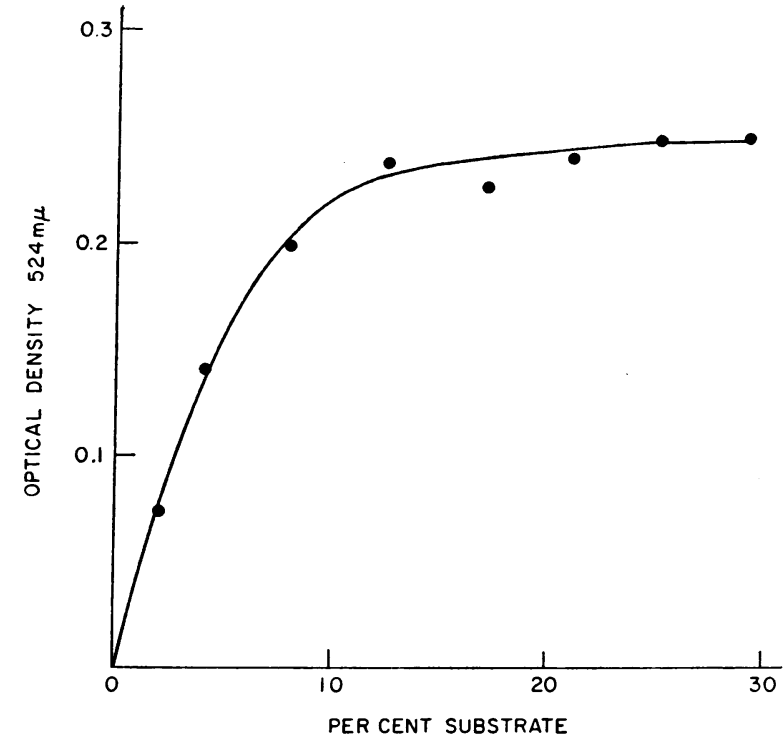

FIGURe 2 Initial rate of phagocytosis as a function of concentration of paraffin oil emulsion. Guinea pig polymorphonuclear leukocytes, $3.11 \mathrm{mg}$ cell protein $/ \mathrm{ml}$, were incubated with different concentrations of Fraction $\mathrm{V}$ emulsion. Samples were taken from each flask (total volume $5 \mathrm{ml}$ ) at $1 \mathrm{~min}$ intervals for $4 \mathrm{~min}$. The initial rate of phagocytosis is expressed as change in optical density at 524 $\mathrm{m} \mu / \mathrm{min}$ during the time that the rate was constant. The concentration of substrate for phagocytosis is expressed as $\frac{\text { volume of emulsion }}{\text { total volume }(5 \mathrm{ml})} \times 100=$ per cent substrate.

tially no Oil Red O was detected in the zero time samples or in samples incubated for $4 \mathrm{~min}$ at $0^{\circ} \mathrm{C}$. The recovery of Oil Red $O$ (amount in cells plus washes per amount added to medium) was $100 \%$. When the cells, after undergoing the usual wash procedure, were incubated again at $37^{\circ} \mathrm{C}$ with shaking for as long as 90 min, they retained $100 \%$ of the Oil Red O that was present at the end of the washing.

With 39 preparations of guinea pig polymorphonuclear leukocytes, the rate of phagocytosis of Fraction $\mathrm{V}$ emulsion was $0.097 \pm 0.025 \mathrm{mg}$ paraffin oil ingested/ $\mathrm{mg}$ cell protein per min (mean $\pm \mathrm{sD}$ ). The rate for rat peritoneal exudate cells expressed in the same units was $0.035 \pm 0.014(n=12)$. For eight preparations of leukocytes from human peripheral blood, a mixed population of cells, the rate was $0.030 \pm 0.016$. In these experiments the paraffin oil concentration was $45 \mathrm{mg} / \mathrm{ml}$ and was in all instances greater than $20 \mathrm{mg} / \mathrm{mg}$ of cell protein. Hence the studies were conducted with saturating amounts of substrate. The kinetics of particle uptake with respect to time course of ingestion, proportionality with cell concentration, and particle concentration were qualitatively similar for the three species. Although 


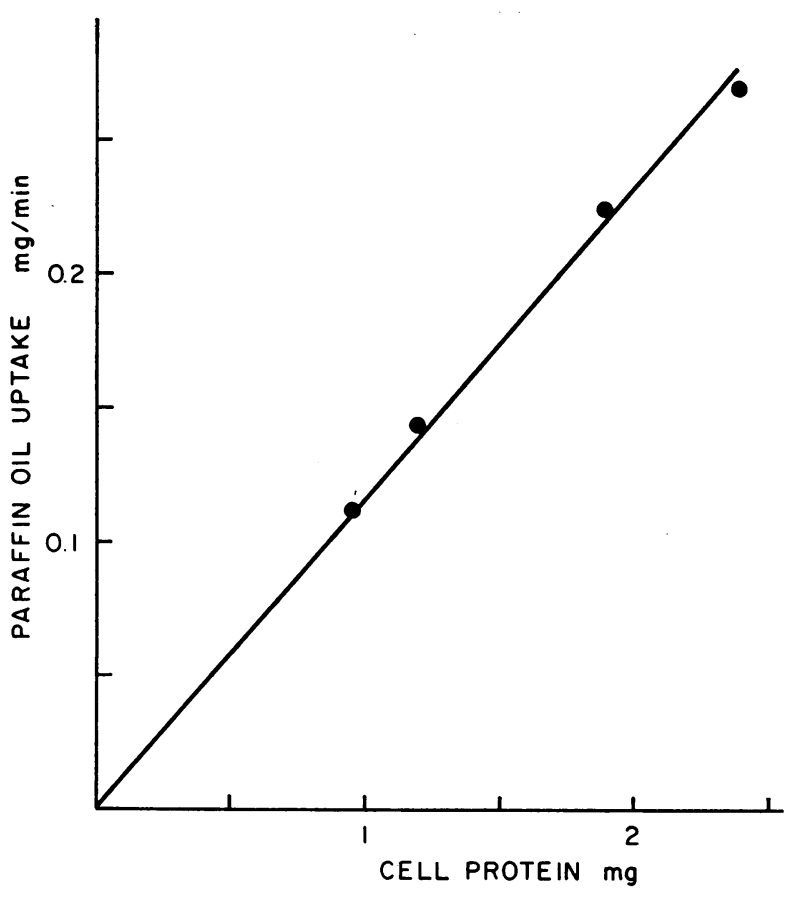

FIGURE 3 Initial rate of phagocytosis as a function of cell concentration. Guinea pig polymorphonuclear leukocytes were incubated for $4 \mathrm{~min}$ with Fraction $\mathrm{V}$ emulsion, $0.2 \mathrm{ml} / \mathrm{ml}$ final volume. The concentration of cells is expressed as milligrams cell protein. Each point is the mean of duplicate values.

this question was not examined in detail, the absolute differences in maximal rates of uptake as expressed above probably reflect differences in homogeneity of the cell population and protein content per cell. Guinea pig exudate cells, because of their homogeneity, ready availability, and lack of tendency to agglutinate, were used for all of the studies described below.

Effects of extracellular medium on phagocytosis. The initial rate of phagocytosis of Fraction $\mathrm{V}$ emulsion was not affected by addition to the medium of $5-20 \mathrm{~mm}$ glucose or fresh guinea pig serum (up to $20 \%$ ). Antiserum to bovine albumin, with or without added guinea pig serum was also without effect. When the effect of extracellular ions was examined, the cells were washed and suspended in Krebs-Ringer phosphate medium lacking the ion in question. The appropriate ion was added where indicated during the $10 \mathrm{~min}$ incubation before addition of the substrate for phagocytosis. Omission of potassium from the medium or inclusion of ouabain, $10^{-4} \mathrm{M}$, did not alter the initial rate of phagocytosis. As shown in Fig. 4, however, omission of magnesium decreased it by about $65 \%$. In medium without calcium or magnesium there was no uptake of Fraction $\mathrm{V}$ emulsion. A maximal rate of phagocytosis of this emulsion was observed in the standard medium which contained $1.27 \mathrm{~mm} \mathrm{MgSO}$ a and $0.92 \mathrm{~mm} \mathrm{CaCl}$.

The relationship between initial rate of phagocytosis and the rate of glucose oxidation. The time course of phagocytosis and of glucose oxidation in the presence of a saturating concentration of Fraction $\mathrm{V}$ emulsion is shown in Fig. 5. Although phagocytosis had essentially ceased after $10 \mathrm{~min}$, the stimulated rate of glucose oxidation was maintained constant for at least $20 \mathrm{~min}$. The time relationships are qualitatively similar to those presented by Michell, Pancake, Noseworthy, and Karnovsky (12) in studies with cellular monolayers ingesting radioactively labeled starch particles. Quantitatively, the rate of uptake is more rapid in the system used here, presumably because of the geometric advantage of cells in suspension over cells adherent to surfaces. The experiment was performed in order to establish the optimal time points for comparing maximal rates of both processes as shown in Fig. 6. The rate of phagocytosis was altered by varying the concentration of Fraction $\mathrm{V}$ emulsion. The increment in glucose oxidation during 20 min of incubation with paraffin oil emulsion was directly proportional to the initial rate of phagocytosis over the entire range investigated.

Effects of pharmacologic agents on the initial rate of phagocytosis. Sodium fluoride, $20 \mathrm{~mm}$, and iodoacetic acid, $10^{-4} \mathrm{M}$, decreased the initial rate of phagocytosis by $60-85 \%$. Dinitrophenol, $10^{-4} \mathrm{M}$, and potassium cyanide, $1 \mathrm{~mm}$, were without effect. As shown in Table I, $N$-ethylmaleimide and colchicine inhibited the rate of

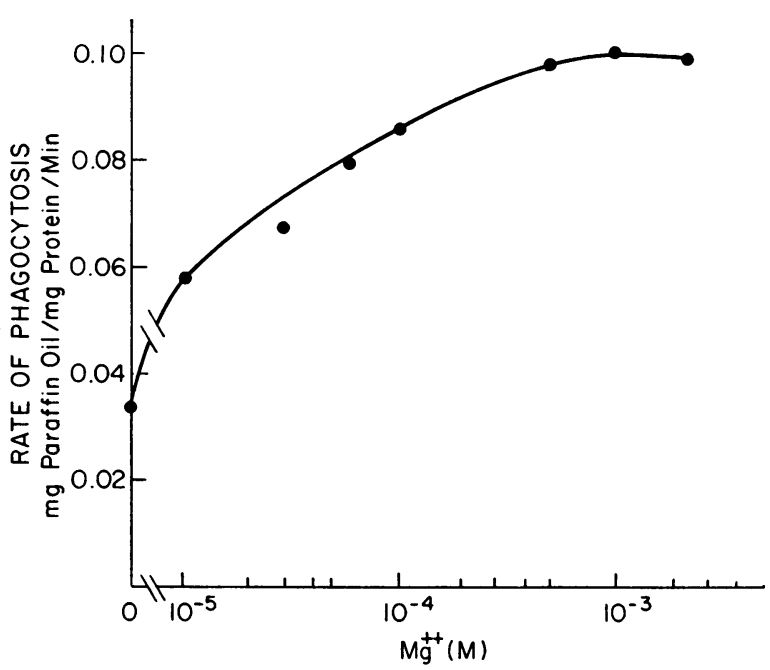

FIgURe 4 Initial rate of phagocytosis of Fraction $\mathrm{V}$ emulsion as a function of $\mathrm{Mg}^{++}$concentration. Cells were suspended in medium from which $\mathrm{MgCl}_{2}$ was omitted. They were incubated $(3.68 \mathrm{mg}$ cell protein $/ \mathrm{ml}$ ) for $4 \mathrm{~min}$ in the presence of $\mathrm{Mg}^{++}$at the final concentration indicated. Each point is the mean of duplicate values. All incubations contained $\mathrm{CaCl}_{2}, 0.97 \mathrm{~mm}$. 


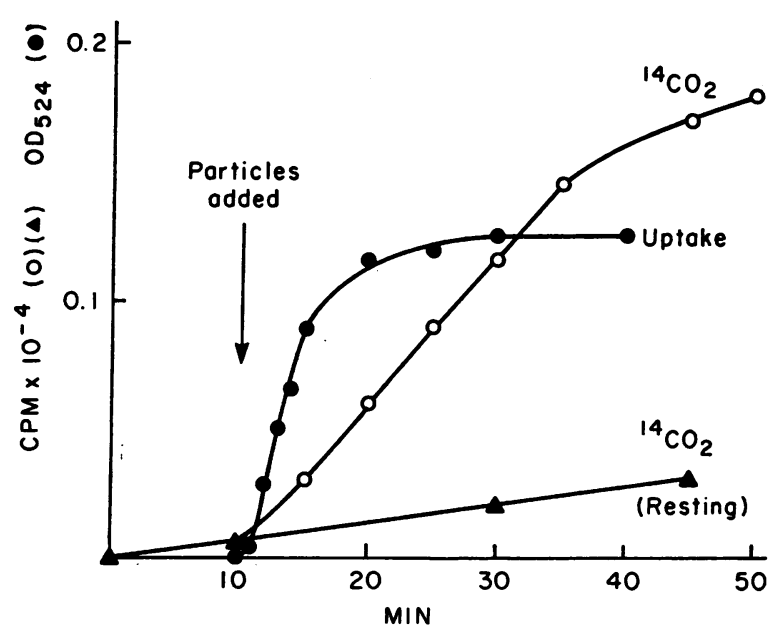

Figure 5 Time course of phagocytosis and oxidation of glucose- $1-{ }^{14} \mathrm{C}$. The medium in all flasks contained $5 \mathrm{~mm}$ glucose. Those used for determination of glucose oxidation contained in addition glucose-1 ${ }^{14} \mathrm{C}$, circa $5 \times 10^{4} \mathrm{cpm} / \mathrm{ml}$. Emulsion particles were added after $10 \mathrm{~min}$ of incubation where indicated $(\bullet, \mathrm{O})$ and flasks containing glucose- $1{ }^{14} \mathrm{C}$ were then sealed for collection of ${ }^{14} \mathrm{CO}_{2}$. Since ${ }^{14} \mathrm{CO}_{2}$ generated in these flasks during the first $10 \mathrm{~min}$ of incubation was not included in the collection, the amount produced in control flasks ( $\Delta$ resting cells) in $10 \mathrm{~min}$ has been added to the observed values for the phagocytosing cells.

TABLE I

Effect of Pharmacologic Agents on the Initial Rate of Phagocytosis

\begin{tabular}{llcc}
\hline \multicolumn{1}{c}{ Addition } & Concentration & $\begin{array}{c}\text { No. of } \\
\text { pairs }\end{array}$ & $\begin{array}{c}\text { Rate of } \\
\text { phagocytosis }\end{array}$ \\
\hline & & & $\begin{array}{c}\text { \% of untreated } \\
\text { control, } \\
\text { mean } \pm \text { sE }\end{array}$ \\
$N$-ethyl maleimide & 0.05 & 4 & $59.5 \pm 8.2^{*}$ \\
& 0.5 & 5 & $31.6 \pm 6.8 \ddagger$ \\
Colchicine & 1 & 4 & $5.5 \pm 3.2 \ddagger$ \\
& 0.001 & 5 & $68.6 \pm 3.7^{*}$ \\
Ethanol & 0.01 & 6 & $54.2 \pm 5.4^{*}$ \\
Hydrocortisone-21- & 0.1 & 5 & $39.8 \pm 1.2 \ddagger$ \\
succinate & 85 & 7 & $76.9 \pm 2.9 \ddagger$ \\
Theophylline & 2.1 & 4 & $26.0 \pm 7.0 \ddagger$ \\
& 1 & 3 & $80.0 \pm 6.5^{*}$ \\
Dibutyryl cyclic AMP & 2 & 3 & $62.7 \pm 1.4^{*}$ \\
Insulin & 1 & 8 & $81.1 \pm 6.3^{*}$ \\
\hline Guinea & $2 \mathrm{mM} / \mathrm{ml}$ & 7 & $112.3 \pm 1.4^{*}$ \\
\hline
\end{tabular}

Guinea pig polymorphonuclear leukocytes were incubated for 10 min with or without additions present at the indicated concentration. Fraction $\mathrm{V}$ emulsion was then added, increasing the volume by $25 \%$, and the incubation was terminated $4 \mathrm{~min}$ later.

${ }^{*} P<0.01$; significance of difference between treated incubations and paired controls.

$\ddagger P<0.001$.

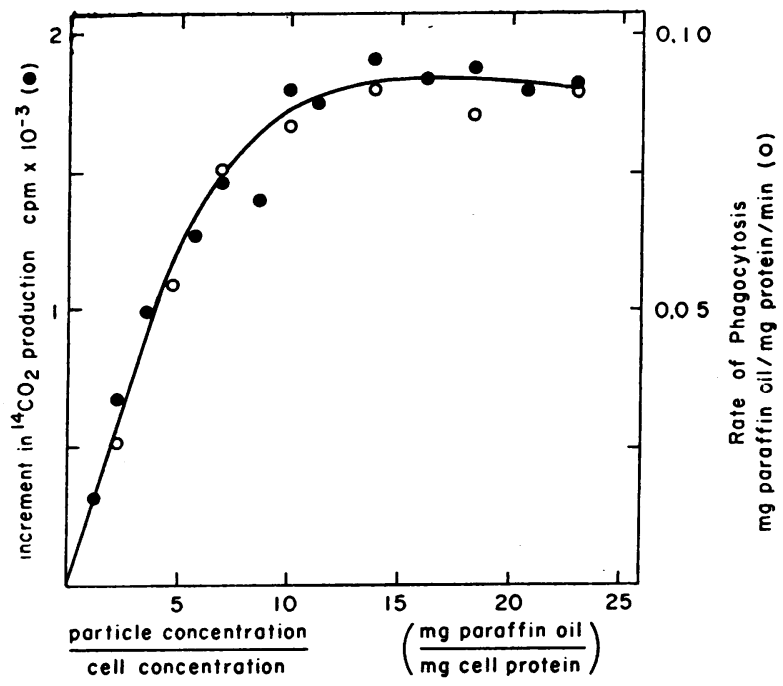

FIGURE 6 Initial rate of phagocytosis and increment in rate of glucose oxidation as a function of substrate to cell concentration ratio. Guinea pig polymorphonuclear leukocytes, $2.66 \mathrm{mg} / \mathrm{ml}$, were incubated in Krebs-Ringer phosphate medium, $\mathrm{pH} 7.4$, with $5 \mathrm{~mm}$ glucose. Varying amounts of paraffin oil emulsion were added to paired flasks, one of each pair containing glucose-1-14 $\mathrm{C}$, about $5 \times 10^{4} \mathrm{cpm} / \mathrm{ml}$ (total volume $5 \mathrm{ml}$ ). The flasks containing glucose-1-14 $\mathrm{C}$ were sealed after addition of particles and assayed for ${ }^{14} \mathrm{CO}_{2}$ after $20 \mathrm{~min}$ of incubation. Total $\mathrm{cpm}$ recovered per flask minus the cpm generated in a control flask incubated with cells but without particles for $20 \mathrm{~min}$ are indicated. The other flasks were sampled at 0,2 , and $4 \mathrm{~min}$ for determination of Oil Red $\mathrm{O}$ uptake.

phagocytosis of Fraction $\mathrm{V}$ emulsion in a dose-related manner. Inhibition of phagocytosis by $N$-ethylmaleimide was similar in rat polymorphonuclear leukocytes (data not shown). Phagocytosis was inhibited by theophylline, dibutyryl cyclic AMP, and hydrocortisone (Table I). Hydrocortisone, $2.1 \mathrm{~mm}$, inhibited uptake of paraffin oil emulsified with calf thymus histone as well as phagocytosis of Fraction V emulsion. Dexamethasone, $10^{-6} \mathbf{M}$, was without effect. Concentrations of ethanol below 85 mM did not inhibit the initial rate of phagocytosis. Insulin caused a small but statistically significant increase in the initial rate of phagocytosis (Table I). Attempts to augment this effect by using cells from rats made diabetic with alloxan were unsuccessful.

Effects of different emulsifiers on the initial rate of phagocytosis of paraffin oil. Crystalline albumin and derivatives of it, lysozyme, histone, gelatin, gelatin derivatives, starch, DEAE-dextran, dextran-sulfate, and detergents yielded emulsions comparable in stability to those prepared with Fraction V. Emulsions prepared with heparin, dextran, and cytochrome $\mathrm{c}$ were somewhat unstable, resulting in deposition of red oil on the walls of the centrifuge tube at the upper level of the super- 
natant wash fluid. These deposits were wiped from the drained tubes using tissue moistened with dioxane.

Emulsions prepared with Fraction V, crystalline albumin, acetylated or succinylated albumin, or gelatin, were readily washed away from cells so that zero time values in phagocytsis studies with these emulsions were negligible (Table II). Zero time values for methylated albumin were significant, and for emulsions prepared with histone, dextran, or DEAE-dextran the zero time values were as much as $55 \%$ of the total after $4 \mathrm{~min}$ of incubation (Table II). Zero time values of starch emulsions were up to $78 \%$ of the total.

Some emulsifiers, e.g., anionic and cationic detergents, lysozyme, and dextran-sulfate had deleterious effects on the cells producing gross agglutination and lysis. Paraffin oil emulsified with the Pluronic detergents was not taken up at all, and addition of albumin or serum to the incubation medium did not induce phagocytosis. In fact, a mixture of emulsions, $50 \%$ Fraction V (with Oil Red O) and 50\% Pluronic (without Oil Red O) was taken up at only about $30 \%$ of the rate at which the Fraction $\mathrm{V}$ emulsion alone was ingested, although cells incubated with Pluronic emulsion exhibited no obvious morphologic changes (light microscopy). Tween 20 emulsion was ingested but at an extremely low rate.

As shown in Table III, emulsions prepared with crystalline albumin were taken up somewhat less rapidly than those made with Fraction V. Acetylated or succinylated crystalline albumin emulsions were ingested at rates equal to or greater than those observed with Fraction $\mathrm{V}$ emulsions. Methylated albumin emulsions on the other hand were taken up much more slowly. When treated with charcoal by the method of Chen (5), Fraction V, crystalline albumin and its acetylated derivative made emulsions that were ingested more

TABLE II

Zero Time Values for Different Emulsions

\begin{tabular}{lc}
\hline \multicolumn{1}{c}{ Emulsion } & $\begin{array}{c}\text { Zero time } \\
\text { value }\end{array}$ \\
\hline & $\begin{array}{c}\text { \% of final } \\
(4 \text { min }) \text { value }\end{array}$ \\
Fraction V & 0 \\
Crystalline albumin & 0 \\
Acetylated crystalline albumin & 0 \\
Methylated crystalline albumin & 27 \\
Gelatin & 0 \\
Histone & 55 \\
Dextran & 47 \\
DEAE-dextran & 53
\end{tabular}

The results of a representative experiment are shown. The experiments were repeated at least twice and similar results obtained.
TABLE III

The Initial Rate of Phagocytosis of Paraffin Oil Emulsified with Different Substances

\begin{tabular}{clc}
\hline Experiment & \multicolumn{1}{c}{ Emulsifying agent } & $\begin{array}{c}\text { Initial rate of } \\
\text { phagocytosis* }\end{array}$ \\
\hline A & Fraction V & 0.178 \\
& Crystalline albumin & 0.150 \\
& Acetylated & 0.208 \\
& Succinylated & 0.179 \\
& Methylated & 0.040 \\
& Horse radish peroxidase & 0.025 \\
B & Histone & 0.126 \\
& Fraction V & 0.108 \\
& Delipidated & 0.069 \\
& Crystalline albumin & 0.090 \\
& Delipidated & 0.077 \\
& Acetylated crystalline albumin & 0.126 \\
C & Delipidated & 0.104 \\
& Crystalline albumin & $0.09 C$ \\
& Gelatin & $0.06 \epsilon$ \\
& Methylated & 0.061 \\
& Polylysyl- & 0.086 \\
\hline
\end{tabular}

Guinea pig polymorphonuclear leukocytes were incubated for $4 \mathrm{~min}$ in Krebs-Ringer phosphate medium, $\mathrm{pH} 7.4$ at $37^{\circ} \mathrm{C}$. The results of representative experiments are shown. All experiments were repeated at least twice and similar results obtained.

* Milligram paraffin oil/milligram cell protein per minute. Values are the means of duplicate determinations.

slowly than those prepared with the respective untreated proteins. The rates of phagocytosis of emulsions prepared with histone and polylysyl-gelatin were similar to those of crystalline albumin emulsion (Table III). The rate of ingestion of DEAE-dextran emulsion was also comparable. Emulsions prepared from dextran (not shown), horseradish peroxidase, gelatin, and methyl gelatin were ingested less rapidly (Table III). Although the absolute rates of phagocytosis were variable from one experiment to another, the relationship of the rate of uptake of one type of emulsion to that of another was consistently reproducible.

Divalent cations were required for phagocytosis of crystalline albumin, acetylated albumin, dextran, and DEAE-dextran emulsions (Table IV) and also for the uptake of succinylated albumin, gelatin, and heparin emulsions (data not shown). Emulsions prepared with histone were ingested without divalent cations in the incubation medium, although these ions stimulated phagocytosis variably $(0-48 \%)$. Engulfment of the histone emulsion occurred even in the presence of $1 \mathrm{~mm}$ EDTA (Table IV). Emulsions prepared with methyl gelatin, polylysyl-gelatin, or cytochrome c were also ingested 
in the absence of divalent cations (data not shown). Starch emulsion particles appeared to be phagocytosed equally well whether or not divalent cations or EDTA were present, but the high zero time values precluded reliable quantification of uptake.

\section{DISCUSSION}

The importance of initial rate for precise quantification of phagocytosis has been discussed by Michell et al. (12). They emphasized that it is preferable to measure the accumulation of particles within cells rather than the disappearance of particles from the incubation medium and that the rate of phagocytosis should be independent of particle concentration. The method used in the present studies fulfills these criteria. It is simple and permits accurate measurement of the initial rate of phagocytosis. It should be noted, however, that since the emulsion droplets are heterodisperse, these substrates cannot be used to investigate phagocytosis of particles of defined size.

The paraffin oil emulsion is easily prepared and inexpensive. Its components, the emulsifier, the hydrocarbon, or the marker, can be varied when needed for specific experiments. Heavy paraffin oil is particularly suitable for the assay because its density (0.89) is low enough to facilitate separation of uningested particles from the cells, but is not so low as to cause floatation of the cells. A crucial attribute of a technique for measuring phagocytosis is its ability to distinguish between particles adsorbed onto the surfaces of leukocytes or trapped in leukocyte clumps from particles actually internalized. In this regard Fraction $\mathrm{V}$ emulsion or crystalline albumin emulsion has no tendency to aggregate or bind nonspecifically to the cells. The evidence for this contention is that zero time values are essentially zero, there is no cell-associated Oil Red $O$ after incubation of cells and particles at zero degrees, and high concentrations of appropriate metabolic inhibitors completely prevent uptake of the emulsion. Furthermore, the rate of phagocytosis is independent of particle concentration when large amounts of emulsion are used. Thus it is possible to employ a large excess of particles thereby ensuring measurement of initial phagocytic rates. Another advantage of the method presented here is that complete extraction of Oil Red $O$ from the washed cell pellets can be visually monitored. The spectrophotometric reading in the visible range obviates the need for spectral quality solvents and minimizes the possibility of unrecognized absorption of light by materials present in cellular extracts. With the technique described here it has been possible to establish kinetics of phagocytosis of precision and detail comparable to those provided by the studies of Michell et al. alluded to above and of Weisman and Korn who
TABLE IV

Effect of Magnesium on the Initial Rate of Phagocytosis of Paraffin Oil Emulsified with Different Substances

\begin{tabular}{lll}
\hline & \multicolumn{2}{c}{$\begin{array}{c}\text { Initial rate of phagocytosis,* } \\
\mathbf{M g}^{++}(1 \mathrm{mM})\end{array}$} \\
\cline { 2 - 3 } \multicolumn{1}{c}{ Emulsifying agent } & \multicolumn{1}{c}{-} & + \\
\hline Crystalline bovine albumin & 0 & 0.100 \\
Acetylated bovine albumin & 0 & 0.138 \\
Methylated bovine albumin & 0.042 & 0.045 \\
Histone & 0.092 & $0.094 \ddagger$ \\
Dextran & 0 & 0.035 \\
DEAE-dextran & 0.002 & 0.080 \\
\hline
\end{tabular}

Guinea pig polymorphonuclear leukocytes were incubated in medium containing $150 \mathrm{~mm}$ sodium, $5 \mathrm{~mm}$ potassium, $12 \mathrm{mM}$ phosphate buffer, and the additions indicated above. Data are expressed as in Table II.

* Milligrams paraffin oil ingested/milligram cell protein per minute.

$\ddagger$ In the presence of $1 \mathrm{mM}$ EDTA (no $\mathrm{Mg}^{++}$present) the rate was 0.049 .

investigated uptake of polystyrene beads by Acanthamoeba (13).

The fact that a relationship exists between the magnitude of stimulation of hexose monophosphate shunt activity and the concentration of particles available for phagocytosis has been well established $(1,14$ 15). It is not surprising, therefore, that the initial rate of phagocytosis determines the degree to which the rate of glucose oxidation is stimulated. Thus the rate of glucose oxidation is a valid although indirect index of phagocytic rate and has been used for this purpose (16). This relationship is emphasized in the context of studies by others with pharmacologic agents used in attempts to alter specifically metabolic aspects of phagocytosis. Reports of certain drugs effecting specific inhibition of metabolic processes such as glucose oxidation or respiration have appeared in which discrepancy between the sensitivity of the assays for phagocytosis and the metabolic measurements may have yielded the erroneous impression that metabolism but not ingestion was impaired. For example, $N$-ethylmaleimide $\left(10^{-4} \mathrm{M}\right)$ has been reported to inhibit the stimulation of glucose oxidation without affecting uptake of polystyrene beads by rat polymorphonuclear leukocytes (17). The tendency of polystyrene beads to stick to the surface of cells (18) may, however, have interfered with accurate estimation of ingestion (by light microscopy). In our studies, $10^{-4} \mathrm{M} N$-ethylmaleimide markedly depressed the rate of uptake of paraffin oil by guinea pig and rat polymorphonuclear leukocytes.

Colchicine has been found to inhibit ingestion of paraffin oil emulsion (Table I), uric acid crystals (19),

Quantitative Studies of Phagocytosis 
and zymosan particles (20) by polymorphonuclear leukocytes and to diminish the degree of stimulation of glucose- $1-{ }^{14} \mathrm{C}$ oxidation associated with phagocytosis (19). On the other hand, it has been reported that colchicine in concentrations comparable to those employed here inhibits degranulation and the increment in oxygen consumption secondary to phagocytosis without altering uptake of streptococci or staphylococci by human leukocytes (21). Michell et al. have pointed out that the incubation medium in that study was essentially devoid of particles at the end of the experiments, implying that variations in phagocytic rate, phagocytic capacity, or both, could not be differentiated (12).

Hydrocortisone 21-succinate, in high concentration (2.1 $\mathrm{mm}$ ) has been reported to depress leukocyte oxygen consumption without affecting ingestion of Staphylococci (22). Particle uptake was quantified in that study by counting particles in cells by light microscopy. We found that $2.1 \mathrm{mM}$ of hydrocortisone 21-succinate caused considerable inhibition of phagocytosis of two types of emulsions. The inaccuracy of counting particles in cells has been documented (13), and the tendency of certain bacteria to attach to the cell surface without being ingested (23) undoubtedly compromises the accuracy further.

In all of the above instances, our assay for the rate of phagocytosis uncovered subtle and occasionally major inhibition of particle uptake by the agents in question when such inhibition had not been appreciated by grosser methods. This technique, in combination with analysis of isolated phagocytic vesicles, has also been used to reexamine the effects of some other drugs thought to effect dissociation of ingestion from other phagocytic events. For example in a published study, ethanol, $85 \mathrm{~mm}$, did not depress ingestion of staphylococci, as determined by the disappearance of the bacteria from the extracellular medium but was found to inhibit chematoxis (24). We observed that ethanol at $85 \mathrm{~mm}$ but not at lower concentrations significantly inhibited the uptake of paraffin oil emulsion.

Bourne, Lehrer, Cline, and Melmon recently reported that theophylline, dibutyryl cyclic AMP, and other agents which probably increase the concentration of cyclic AMP in human leukocytes all inhibited uptake of ${ }^{32} \mathrm{P}$-labeled Candida albicans by these cells (25). The degree of inhibition of phagocytosis described is comparable to the diminution in initial rate of uptake observed by us. Bourne et al. (25) noted that theophylline and dibutyryl cyclic AMP depressed candidacidal activity of human leukocytes, and this depression was considered disproportionate to the degree of inhibition of phagocytosis. They postulated that the major mechanism of action of these agents may have been inhibition of degranulation. A similar hypothesis was recently advanced by Weissmann, Dukor, and Zurier to explain how theophylline and dibutyryl cyclic AMP apparently inhibited the release of lysosomal enzymes from phagocytosing leukocytes into the extracellular medium (20). We investigated this question by incubating guinea pig polymorphonuclear leukocytes with Fraction V emulsion in the presence and absence of $1 \mathrm{~mm}$ theophylline, $1 \mathrm{~mm}$ dibutyryl cyclic AMP, both of these agents together, and with $10^{-4} \mathrm{M}$ colchicine. The cells were also fed emulsion prepared with delipidated crystalline albumin. Phagocytic vesicles were isolated as previously described (2), and degranulation was quantified directly by determining the ratios of acid phosphatase and of $\beta$-glucuronidase to protein and to Oil Red $O$ in the isolated vesicles. Granulocytes ingesting delipidated albumin emulsion or Fraction $\mathrm{V}$ emulsion in the presence of theophylline, dibutyryl cyclic AMP, or colchicine took up less Oil Red $\mathrm{O}$ than did cells incubated with Fraction $\mathrm{V}$ emulsion alone; but the ratios of enzymes to protein and Oil Red $\mathrm{O}$ in phagocytic vesicles from all samples of cells were similar. Thus our findings provide no evidence that the agents tested inhibit degranulation.

Surface charge $(26,27)$ has been considered of importance in determining the acceptability of particles for ingestion. Paraffin oil particles prepared with a variety of emulsifiers were ingested by polymorphonuclear leukocytes. The emulsifiers were selected and modified to create particles with differences in net surface charge. We found that particles emulsified with albumin, acetylated albumin, and succinylated albumin (net strong negative charge at $\mathrm{pH} 7.4$ ), histone, polylysyl-gelatin, and DEAE-dextran (net strong positive charge at $\mathrm{pH}$ 7.4) were ingested at comparable rates. On the other hand, dextran, probably starch (weak negative charge), methylated albumin, gelatin, and horseradish peroxidase (weak positive charge) emulsions were engulfed relatively slowly. Emulsions made with Tween 20 or Pluronic, nonionic detergents were taken up poorly or not at all. It is likely that the particles carried the net charge of the emulsifier, because it has been shown that minute amounts of albumin confer the electrophoretic mobility of that protein onto paraffin oil particles (28). In general, it appears that a particle with a strong net charge, either positive or negative is ingested more avidly than an uncharged or weakly charged particle. Although methylated gelatin has a greater net positive charge than gelatin, emulsion prepared with the former was not ingested more rapidly than emulsion made with the latter. In the light of this finding it is of interest that methylated albumin emulsion was taken up very slowly, and emulsion prepared with Pluronic polyols which have methyl side groups, were not engulfed. Studies of solid-liquid interfaces 
have shown that methyl groups as outermost substitutents decrease adhesiveness (29). Pluronic polyols are used to emulsify an experimental fluorocarbon blood substitute (30), and it is appropriate that such particles are not phagocytized, but the possibility that the detergent inhibits phagocytosis of other particles deserves further investigation.

Polystyrene beads, which have a negative surface charge at physiologic $\mathrm{pH}$ (31) require divalent cations, preferably magnesium, for ingestion by leukocytes (32, 33). Magnesium has also been found to enhance the phagocytosis of $E$. coli by granulocytes (34). Metzger and Casarett reported that divalent cations, particularly calcium, stimulated the uptake of metal oxide particles with net negative charge, but not of carbon particles (presumably uncharged) or positively charged $\mathrm{Fe}_{2} \mathrm{O}_{3}$ particles (35). In the present study, divalent cations were required for the uptake of particles emulsified with albumin or acetylated albumin, negatively charged agents, but were also required for ingestion of particles emulsified with dextran, DEAE-dextran, and gelatin, weakly charged or cationic substances. Uptake of histone, lysine-rich histone, methylated albumin, methylated gelatin, polylysyl-gelatin, and cytochrome c emulsions did not require $\mathrm{Mg}^{++}$although particle uptake could occasionally be stimulated by divalent cations. The histone and cytochrome c used in these experiments had been dialyzed against EDTA. Moreover, emulsions of certain derivatives of albumin and gelatin did not require magnesium for uptake, although the proteins were not exposed to divalent cations during derivatization. Thus, the effect of divalent cations on particle uptake appears to depend on the nature of the phagocytic substrate, but does not bear a simple relationship to net surface charge of the particle.

One would like to ascribe the differences in rates of uptake of emulsions prepared with different substances to differences in their surface properties that influence cell-particle interaction. In addition to considerations of toxicity and instability of certain emulsions, however, small differences in mean particle size could alter the quantity of Oil Red $\mathrm{O}$ incorporated into the cells. Such size differences were not detected when the size distribution of particles of different emulsions was determined by sequential Millipore filtration (Millipore Corp., Bedford, Mass.), but this method is relatively crude. The tendency of some emulsions to adhere to cells without being ingested adds another difficulty. The emulsifiers that we have used are complex macromolecules whose characteristics in solution may not allow prediction of behavior at an oil-water interface. Moreover, the derivatization procedures are not entirely specific. Thus, we hesitate to force conclusions on the basis of the limited data preserved here, but believe that this approach may shed light on the recognition mechanism of phagocytosis.

\section{ACKNOWLEDGMENTS}

We thank Mrs. B. Maskett for performing the paper electrophoretic analyses; Mr. Richard Zobel and Miss Susan Ely for expert technical assistance, and Dr. Warren $\mathrm{H}$. Evans for helpful suggestions.

\section{REFERENCES}

1. Sbarra, A. J., and M. L. Karnovsky. 1959. The biochemical basis of phagocytosis. I. Metabolic changes during the ingestion of particles by polymorphonuclear leukocytes. J. Biol. Chem. 234: 1355.

2. Stossel, T. P., T. D. Pollard, R. J. Mason, and M. Vaughan. 1971. Isolation and properties of phagocytic vesicles from polymorphonuclear leukocytes. J. Clin. Invest. 50: 1745.

3. Bollinger, J. N. 1970. Metabolic fate of mineral oil adjuvants using ${ }^{14} \mathrm{C}$-labeled tracers. I. Mineral oil. J. Pharm. Sci. 59: 1084.

4. Stossel, T. P., F. Murad, R. J. Mason, and M. Vaughan. 1970. Regulation of glycogen metabolism in polymorphonuclear leukocytes. J. Biol. Chem. 245: 6228.

5. Chen, R. F. 1967. Removal of fatty acids from serum albumin by charcoal treatment. J. Biol. Chem. 242: 173.

6. Riordan, J. F., and B. L. Vallee. 1967. Acetylation. In Methods in Enzymology. S. P. Colowick and N. O. Kaplan, editors. Academic Press Inc., New York. 11: 565.

7. Klotz, I. M. 1967. Succinylation. In Methods in Enzymology. S. P. Colowick and N. O. Kaplan, editors. Academic Press Inc., New York. 11: 576.

8. Fraenkel-Conrat, H., and H. S. Olcott. 1945. Esterification of proteins with alcohols of low molecular weight. J. Biol. Chem. 161 : 259.

9. Sela, M., and R. Arnon. 1960. Studies on the chemical basis of the antigenicity of proteins. I. Antigenicity of polypeptidyl gelatins. Biochem. J. 75: 91 .

10. Ben-Ishai, D., and A. Berger. 1952. Cleavage of $N$-carbobenzoxy groups by dry hydrogen bromide and hydrogen chloride. J. Org. Chem. 17: 1564.

11. Becker, R. R., and M. A. Stahmann. 1953. Polypeptide formation by reaction of $N$-carboxy-amino acid anhydrides in buffered aqueous solutions. J. Biol. Chem. 204: 737.

12. Michell, R. H., S. J. Pancake, J. Noseworthy, and M. L. Karnovsky. 1969. Measurement of rates of phagocytosis. The use of cellular monolayers. J. Cell. Biol. 40: 216 .

13. Weisman, R. A., and E. D. Korn. 1967. Phagocytosis of latex beads by Acanthamoeba. I. Biochemical properties. Biochemistry. 6: 485.

14. Iyer, G. Y. N., M. F. Islam, and J. H. Quastel. 1961. Biochemical aspects of phagocytosis. Nature (London). 192: 535.

15. Roberts, J. H., and J. H. Quastel. 1963. Particle uptake by polymorphonuclear leukocytes and Ehrlich ascitescarcinoma cells. Biochem. J. 89: 150.

16. Mickenberg, I. D., R. K. Root, and S. M. Wolff. 1970. Leukocyte function in hypogammaglobulinemia. J. Clin. Invest. 49: 1528.

Quantitative Studies of Phagocytosis 
17. Reed, P. W. 1969. Glutathione and the hexose monophosphate shunt in phagocytizing and hydrogen peroxidetreated rat leukocytes. J. Biol. Chem. 244: 2459.

18. Ulrich, F., and D. B. Zilversmit. 1970. Release from alveolar macrophages of an inhibitor of phagocytosis. Amer. J. Physiol. 218: 1970.

19. Goldfinger, S. E., R. R. Howell, and J. E. Seegmiller. 1965. Suppression of metabolic accompaniments of phagocytosis by colchicine. Arthritis Rheum. 8: 1112 .

20. Weissmann, G., P. Dukor, and R. B. Zurier. 1971. Effect of cyclic AMP on release of lysosomal enzymes from phagocytes. Nature (London). 231: 131.

21. Malawista, S. E., and P. T. Bodel. 1967. The dissociation by colchicine of phagocytosis from increased oxygen consumption in human leukocytes. J. Clin. Invest. 46: 786.

22. Mandell, G. L., W. Rubin, and E. W. Hook. 1970. The effect of an NADH oxidase inhibitor (hydrocortisone) on polymorphonuclear leukocyte bactericidal activity. $J$. Clin. Invest. 7: 1381.

23. Ulrich, F. 1971. Phagocytosis of $E$. coli by enzymetreated alveolar macrophages. Amer. J. Physiol. 220: 958.

24. Brayton, R. G., P. E. Stokes, M. S. Schwartz, and D. B. Louria. 1970. Effect of alcohol and various diseases on leukocyte mobilization, phagocytosis and intracellular bacterial killing. N. Engl. J. Med. 282: 123.

25. Bourne, H. R., R. I. Lehrer, M. J. Cline, and K. L. Melmon. 1971. Cyclic $3^{\prime}, 5^{\prime}$-adenosine monophosphate in the human leukocyte: synthesis, degradation, and effects on neutrophil candidacidal activity. J. Clin. Invest. 50: 920.
26. Fenn, W. O. 1921. The phagocytosis of solid particles. III. Carbon and quartz. J. Gen. Physiol. 3: 575.

27. Ponder, E. 1928. The influence of surface charge and of cytoplasmic viscosity on the phagocytosis of a particle. J. Gen. Physiol. 11: 757.

28. Abramson, H. A. 1929. Electrokinetic phenomena. I. The adsorption of serum proteins by quartz and paraffin oil. J. Gen. Physiol. 13: 169.

29. Baier, R. E., E. G. Shafrin, and W. A. Zisman. 1968 Adhesion: mechanisms that assist or impede it. Science (Washington). 162: 1360.

30. Spitzer, H. L., G. Sachs, and L. C. Clark, Jr. 1970. Fluorocarbon effects on tissue metabolism. Fed. Proc. 29: 1746.

31. Van den Hul, H. J., and J. W. Vandefhoff. 1968. Wellcharacterized monodisperse latexes. J. Colloid Interface Sci. 28: 336.

32. Wilkins, D. J., and A. D. Bangham. 1964. The effect of some metal ions on in vitro phagocytosis. J. Reticuloendothel. Soc. 1: 233.

33. Henon, M., and A. Delaunay. 1966. Action exercée in vitro, par les ions $\mathrm{Ca}^{++}$et $\mathrm{Mg}^{++}$sur la sensibilité chimiotactique et le pouvoir phagocytaire de leucocytes polynucléaires. Ann. Inst. Pasteur Lille. 111: 85.

34. Leirer, R., H. Meyer, and G. Steinbach. 1969. Einfluss der magnesiumkonzentration des blutserums auf die phagozytoseaktivitat der blutphagozyten. Arch. Exp. Veterinaermed. 23: 1021.

35. Metzger, G. V., and L. J. Casarett. 1967. Some effects of divalent cations on in vitro phagocytosis. Adv. Exp. Med. Biol. 1: 163. 